\title{
The Management of eLearning at University of KKU, Abha
}

\author{
http://dx.doi.org/10.3991/ijet.v8i1.2333 \\ Fatima AL-Saif, Anandhavalli \\ King Khalid University, Abha, Saudi Arabia.
}

\begin{abstract}
Learning, of late, has been witnessing an unprecedented expansion as an opportunity for higher education. This expanding alternative mode calls for ensuring and imparting a sound and qualitative education. So the present case study made an attempt to discuss key aspects of a quality management model for eLearning currently operating at the University of $\mathrm{KKU}$ and illustrates the issues related to the quality dimensions of e-learning. Some of these dimensions are: learning process, administrative processes, teaching materials, resources and SWOT (Strengths, Weakness, Opportunities, Threats) analysis etc. This study reiterates the relevance of imparting qualitative education through e-learning for quality improvement in ways that facilitate how staff are empowered and supported to develop meaningful eLearning resources for students, how quality improvement is managed, and how organizational learning takes place. The findings of the study further demonstrate that if the concept of e-learning is imparted with a better approach and perspective, the reach will be phenomenal.
\end{abstract}

Index Terms-e-learning, e-knowledge, On-Line higher education, Quality improvement.

\section{INTRODUCTION}

Online learning model has emerged as a major higher education option before the global student community in general and Arab student population in particular. Higher education institutions operating in Middle East countries are making efforts to re-adjust in the light of the contemporary challenges While advanced countries responded to these pressures of Globalization rather more successfully with their vast resources, the Arab nations are still in the process of designing strategies to re-adjust to the dynamic phase of global reforms in the higher education sector.

The last two decades have witnessed a revolution caused by rapid development of Information and Communication Technology (ICT). ICT has changed the dynamics of various industries as well as influenced the way people interact and work in the society $[21,3,6]$. Quality of education includes infrastructure, teachers, students and the processes Quality is the main challenge for education system in KKU.

\section{THE CONCEPT OF QUALITY}

The word quality itself stems from the Latin qua litas which means - of what kind. The concept of quality in education is multidimensional and embraces all functions and activities in the academic sphere. It involves quality of students, instructors/facilitators, instruction, facilities and equipment, academic programmes, curricula and assessment of students' performance. The concept of quality is relative, subjective and variable $[2,13,18]$ defines quality as fitness of purpose, while [10] views quality as appropriateness of resources available to education. [1] maintain that the concept of quality varies from that of providing special services to conforming to standards or fitness for purpose. Quality is the base line standard in education which can be measured on a scale of reference. It is an expression of standard or the means by which a certain set standard in education can be achieved [15]. The quality according to [5] may include quantitative elements such as completion rates, student performance, and student evaluations of the learning experience.

Viewed from this perspective, quality in learning involves quality of educational inputs, processes and outputs in its totality. Quality outputs could be viewed in terms of achievement i.e. what the students learn in terms of skills, knowledge, attitude and behaviour; standard i.e. the official learning and what the society expects; attainment i.e. number of students who have completed prescribed academic programmes and quality of degrees or certificates awarded.

\section{THE CONCEPT OF E-LEARNING}

E-learning is the process to learn anytime anywhere by using computer. E-learning is a general term for education, training and information delivered by computers. It puts the emphasis on the gathering of skills and knowledge. Taking e-learning as a tool to teach and learn [9] explains the concept of e-learning in the following words; "e-learning is using the Internet to teach and learn, it includes communication, student submission of work, teacher to student and student to student communication, content delivery and enrichment, using the Internet as a research tool, and using the Internet as a publishing tool. E-Learning is a tool, like writing and speaking, that is used to teach and learn. The Internet provides a huge array of evolving tools that can enhance the teaching process, selecting and using these tools is E-learning".

Significance of e-Learning in Education

- Because of its wider accepted concept, e-learning has a positive and developmental role in education. Elearning can be used as informative, situating, constructive and communicative tool in the process of education [11]. E-learning also allows the creation of digital resources like digital libraries where the students, teachers and professionals can access research material and course material from any place at any time $[3,7,14]$.

- E-learning in education develops higher order skills such as collaborating across time and place and solving complex real world problems $[4,3,16,12]$. 
- Eliminating time barriers in education for learners as well as teachers [20, 17, 8, 21, 3].

- Eliminating geographical barriers as learners can log on from any place $[20,17,8,21,3]$.

- Asynchronous interaction is made possible leading to thoughtful and creative interaction [20, 21, 3].

- Enhanced group collaboration made possible via ICT $[19,3]$.

- New educational approaches can be used [20].

- It can provide speedy dissemination of education to target disadvantaged groups $[21,6]$.

- It offers the combination of education while balancing family and work life $[21,3]$

- It enhances the international dimension of educational services [21].

- It allows for just in time and just enough education for employees in organizations.

- It can also be used for activities like health campaigns and literacy campaigns [21].

All these activities create a digital identity of the student and connect all the stakeholders in the education. It also facilitates inter disciplinary research [6].

\section{E-LEARNING IN KKU}

\section{A. The e-Learning Deanship at King Khalid University}

The eLearning Deanship (ELD) at King Khalid University was established in the year $1426 \mathrm{H}$. as part of the continuous University efforts to provide the latest scientific methodologies to improve the educational process. Since then the eLearning Center has performed various activities and roles and had many experiences in deploying technology in education and developing skills and abilities of the University employees. The eLearning Deanship has relaunched its services after considerable efforts of planning and preparations for a new phase in which eLearning in KKU is intended to be taken to a new level of integration and completeness.

\section{B. KKU's Goals and Related Actions for eLearning}

KKU's vision for eLearning is to be recognized as the leader in eLearning and e-Knowledge in the Kingdom of Saudi Arabia and to be recognized as a high performer in eLearning professional circles, internationally. KKU's mission for eLearning is to embed eLearning in all KKU teaching and learning processes and to enable effective eLearning practices.

\section{Goals for eLearning}

$\mathrm{KKU}$ is pursuing four goals for eLearning:

*Goal \#1: Establish "eLearning for everyone."

*Goal \#2: Enable KKU faculty members to develop, share, reuse, and modify reusable learning resources and knowledge resources.

*Goal \#3: Leverage the tools of eLearning to "mitigate" institutional pain-points.

* Goal \#4: Achieve sector-leading rates of improvement in KKU's impact and capabilities in areas relating to eLearning. These goals are described below.

Goal \#1: Establish "eLearning for everyone.
Build the organizational capacity that enables every authorized student, faculty, and staff to participate in and benefit from eLearning.

Goal \#2: Enable KKU faculty members to develop, share, reuse, and modify reusable learning resources and knowledge resources.

This goal has an internal and external focus. The internal focus involves developing the capacity of faculty members and faculties to develop, repurpose, and share learning and knowledge resources in their learning and scholarly activities, and to build up their confidence and their skills so that they experience both early success and sustained improvement, eventually being able to use eLearning in a wide range of tasks, appropriately, at speed, confidently, efficiently and effectively. The external focus involves partnerships that will provide access to open learning resources for use at KKU, plus access to insights in how to make effective use of those resources, enabling the University to accelerate its access to worldclass learning resources and make a performance leap in a short period of time. The external focus also involves providing KKU-developed/adapted learning and knowledge resources for use outside KKU.

Goal \#3: Leverage the tools of eLearning to "mitigate" institutional pain points. Goal \#1 is a multi-year campaign to broadly develop eLearning capacity and raise the level of practice. Goal \#3 is both immediate and long term. It involves selectively and rapidly leveraging the tools of eLearning to mitigate significant institutional pain points that have a bearing on the institutional effectiveness of eLearning such as the following:

-Faculty shortages and unequal distribution in particular disciplines and campus locations;

-Issues relating to the education of women;

-Issues relating to student engagement and performance;

-Quality assurance and accreditation; and

-Need for greater alignment between relevant strategies, for example, those for ICT, for learning and teaching, and for human resources (HR).

Goal \#4: Achieve sector-leading rates of improvement in KKU's impact and capabilities in areas relating to eLearning. Exploit KKU investments in eLearning and change management, to develop internationally-admired ("top tier") rates of improvement in KKU's impact and capabilities.

- Use KKU eLearning systems to support the development and sharing of e-Knowledge across communities of practice.

Perform at or above international norms regarding support for: teaching and learning, scholarship and research involving eLearning, and community involvement.

Exploit that high performance to raise the visibility of KKU and establish KKU as a preferred partner for high-status international projects relevant to the needs of KSA and for global networks of excellence in eLearning and related areas.

d. Related Actions for Each Goal

KKU shall follow a manageable number of actions for each of its four goals.

Goal \#1: Establish "eLearning for everyone" at KKU. 
- Action 1.1: Develop and deploy an integrated environment to enable KKU faculty and students to integrate technology into their teaching and learning activities.

- Action 1.2: Furnish continuous support, training, incentives, rewards, and encouragement for faculty in the valuable integration of technology into the teaching and learning activities.

- Action 1.3: Engage KKU faculty and students in eLearning activities and develop their capacity to benefit from them. For students, enable them to develop more independence in learning and routinely create and share learning resources and knowledge resources.

These actions will require the synchronization of eLearning training and system introduction, to benefit everyone maximally. In terms of concurrent actions for particular groups:

-Provide Deans and Colleges with a range of ways to engage KKU faculty in eLearning activities and develop their capacity to benefit from them.

-Provide faculty with a range of ways to engage students in eLearning.

-Provide students with a range of ways to develop more independence in learning and routinely create and share learning resources and knowledge resources.

-Evaluate the engagement of KKU faculty and students in eLearning activities.

-Provide KKU management with per-course information on levels of eLearning usage by their faculty and students

Goal \#2: Enable KKU faculty members to develop, share, reuse, and modify reusable learning resources and knowledge resources (including resources from other institutions).

- Action 2.1: Develop a policy on the processes to be followed for all of these; align with legal

requirements (copyright); train faculty in following the policy as part of training them to develop courseware and use the tools.

- Action 2.2: Obtain and validate (quality-assure) external resources that meet the needs of faculties, then document each step that faculty must take to adapt resources for KKU use.

- Action 2.3: Provide rewards (incentives, recognition), resources (tools, grants, release time, just-in-time support with graphics) for faculty to modify materials (localize into Arabic), to develop new materials, to work with others (collaboration, group work).

Goal \#3: Leverage the tools of eLearning to "mitigate" institutional pain points.

- Action 3.1: (Faculty shortages) Create e-versions of face-to-face courses, also components of courses (learning objects), and train faculty and students to re-use them in other locations and to work through with local mentors/Teaching Assistants, partnerships and external materials.

- Action 3.2: (Girls' Education) Create mechanism for sharing courses across KKU campuses.

- Action 3.3: (Student engagement and performance) Provide tools for peer-to-peer engagement(collaborate in creating joint work); to enable students to create their personal ePortfolio; to publish their best work; to benchmark their work against $\mathrm{A} / \mathrm{B} / \mathrm{C}$ students, so that they know where to put more effort in, what standard to aim for, and how to reach that standard

- Action 3.4 (Evolving from a dispersed university to a distributed university). To a large extent, many of the problems addressed in Actions 3.1 and 3.2 result from KKU being a collection of dispersed campuses that have been merged together. Lacking seamless technologies and systems, students at the different campuses do not have the same experiences and level of service. The action here is to create lightweight (meaning easy to implement) interim solutions, as steps towards a fully distributed university. An example to be explored is to use the eLearning architecture to capture e-versions of the desired experiences, and to then deliver those e-versions remotely using that day's best-available combination of $\mathrm{KKU}$ services at particular locations.

Goal \#4: Achieve sector-leading rates of improvement in KKU's impact and capabilities in areas relating to eLearning.

- Action 4.1. Extend ICT systems to measure KKU performance and benchmark against international standards for teaching and learning. Extend existing campus-wide information systems, to provide an easy way to track changes and rates of change in key performance data (accessibility of Internet services across campus).

- Action 4.2. Support pilot projects and codify best practice in teaching, scholarship, and community service. Use KKU eLearning systems to support pilot projects in faculties to codify and share external and internal "eKnowledge" such as insights from communities of practice and from individual faculty about teaching, research/scholarship, community service.

- Action 4.3. Provide KKU with ways to raise the profile and effectiveness of faculty. For example, these include eLearning and e-Knowledge systems, e-Portfolios and Social Networking tools to develop the professional networks of KKU faculty, to increase faculty access to eLearning content, contacts and tools, and to raise their global visibility so that they can join high-quality international projects and networks of excellence, and be coauthors on prestigious publications.

- Action 4.4: Develop maximum possible operational compliance with national and international quality practices and recommendations. Set up a panel to review the quality of existing courses, and assess which ones are good enough to be made available immediately in eversions.

- Action 4.5: Develop partnership relationships with international institutions. Explore and evaluate possible partnership relationships. Test them out through pilot projects bringing KKU together with internationallyrecognized leaders in eLearning.

e. Deanship units

In order for the deanship to offer the right services with the desired quality, it was structured to have units and active teams each specializing in part of the service and all integrate to form the body of the deanship. Below is a summary of the deanship units and teams with their responsibilities: 
TABLE I.

DEANSHIP UNITS

\begin{tabular}{|c|c|}
\hline $\begin{array}{l}\text { Name of the } \\
\text { Team }\end{array}$ & Description / Responsibilities \\
\hline $\begin{array}{l}\text { Administrative } \\
\text { Management }\end{array}$ & $\begin{array}{l}\text { Responsible for } \\
\text { - Supervising the eLearning systems projects } \\
\text { and setting plans for systems operations. } \\
\text { - Setting technical and administrative standards } \\
\text { - Coordinating between the different university } \\
\text { departments in relation to eLearning. }\end{array}$ \\
\hline Training & $\begin{array}{l}\text { - Planning for faculty members training on } \\
\text { eLearning systems and skills, } \bullet \text { Conducting } \\
\text { training, Preparing training materials. }\end{array}$ \\
\hline $\begin{array}{l}\text { The eLearning } \\
\text { Team }\end{array}$ & $\begin{array}{l}\text { - Setting and executing plans for eLearning } \\
\text { deployment. } \\
\text { - Providing support and consultation for } \\
\text { faculty members. } \\
\text { - Maintaining and administering the deanships } \\
\text { website. }\end{array}$ \\
\hline The Web Team & $\begin{array}{l}\text { - Design work for the deanship; printed } \\
\text { materials and web based, Design work in } \\
\text { support for faculty members for educational } \\
\text { content and Audio-visual services including } \\
\text { recording and video montage. }\end{array}$ \\
\hline $\begin{array}{l}\text { Systems and } \\
\text { support }\end{array}$ & $\begin{array}{l}\text { - Supervising all IT related work to ensure a } \\
\text { stable working infrastructure. } \\
\text { - Providing support for students and faculty } \\
\text { members on systems usage and technical } \\
\text { issues. }\end{array}$ \\
\hline Studio Team & $\begin{array}{l}\text { - Task of this group to photograph and docu- } \\
\text { ment the lectures, seminars, internal and } \\
\text { external and the work of editing. }\end{array}$ \\
\hline $\begin{array}{l}\text { Research and } \\
\text { Innovation } \\
\text { Team }\end{array}$ & $\begin{array}{l}\text { - Supervise development projects of learning } \\
\text { and teaching through innovation and innova- } \\
\text { tive practices using modern technology. } \\
\text { - Supervise programs of innovation and } \\
\text { researches for faculty members and students. } \\
\text { - Study and search for new international } \\
\text { initiatives and best practices in e-learning. }\end{array}$ \\
\hline
\end{tabular}

KKU eLearning and eKnowledge Platform

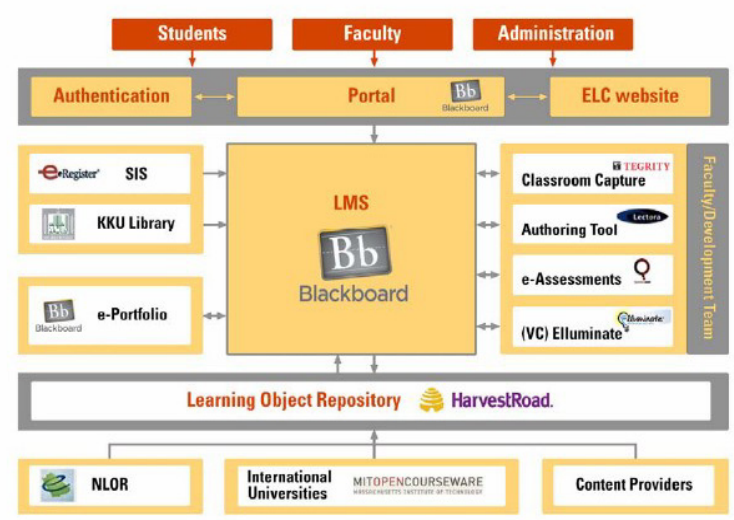

Figure 1. e-Learning and e-Knowledge Platform
TABLE II.

AVAILABLE ELECTRONIC SYSTEM \& TOOLS

\begin{tabular}{|c|c|}
\hline System & Description \\
\hline $\begin{array}{l}\text { Learning Management } \\
\text { System (Blackboard) } \\
\text { Http://lms.kku.edu.sa }\end{array}$ & $\begin{array}{l}\text { The central component in the } \\
\text { eLearning platform of KKU. Used } \\
\text { to offer courses, and manage content } \\
\text { and users. }\end{array}$ \\
\hline $\begin{array}{l}\text { Electronic Testing } \\
\text { (Question mark) } \\
\text { http://qm.kku.edu.sa }\end{array}$ & $\begin{array}{l}\text { Question mark is an electronic } \\
\text { testing application with great } \\
\text { features. }\end{array}$ \\
\hline $\begin{array}{l}\text { (Tegrity) } \\
\text { http://tegrity.kku.edu.sa }\end{array}$ & $\begin{array}{l}\text { This application enables faculty } \\
\text { members to record their classes in } \\
\text { video and offer them on the course } \\
\text { site. Tegrity is integrated with } \mathrm{Bb} \text {. }\end{array}$ \\
\hline $\begin{array}{l}\text { Virtual Classroom } \\
\text { (Elluminate) } \\
\text { http://vc.kku.edu.sa }\end{array}$ & $\begin{array}{l}\text { Enables video communication } \\
\text { between participants in real time. } \\
\text { Sessions can be recorded for future } \\
\text { review. }\end{array}$ \\
\hline $\begin{array}{l}\text { Students Mail } \\
\text { http://mail.ekku.edu.sa }\end{array}$ & $\begin{array}{l}\text { Mail and collaboration tools for all } \\
\text { KKU students. }\end{array}$ \\
\hline $\begin{array}{l}\text { ePortfolios } \\
\text { (Bb ePortfolio) } \\
\text { http://lms.kku.edu.sa }\end{array}$ & $\begin{array}{l}\text { An ePortfolio for all faculty mem- } \\
\text { bers and students. }\end{array}$ \\
\hline $\begin{array}{l}\text { Learning objects Reposi- } \\
\text { tory } \\
\text { (Hive) } \\
\text { http://lor.kku.edu.sa }\end{array}$ & $\begin{array}{l}\text { Offers a modern mechanism for } \\
\text { storing and sharing digital content. } \\
\text { The system is connected to the } \\
\text { national and LOR international } \\
\text { repositories. }\end{array}$ \\
\hline
\end{tabular}

\section{E-LEARNING AND E-KNOWLEDGE PLATFORM}

The eLearning Center has designed and deployed a world-class technology platform to support eLearning and e-Knowledge processes at KKU. Figure 1 depicts this platform.

This platform combines best-of-breed applications. It also features seamless integration between Blackboard and all the other applications such as Tegrity, Elluminate, and so forth. Students, faculty, and administrators achieve authorized/authenticated access through the Blackboard portal to a robust, fully integrated learning management system (LMS) and supporting applications and knowledge resources. This LMS extracts data from the student information systems (SIS), and in the future the KKU library, and Blackboard's e-Portfolio. It also is supported by the Classroom Capture Application, Authoring Tools, eAssessments, and Virtual Classroom Tools. A learning object repository (LOR) can share learning objects drawn from a variety of international open learning resources and content providers.

ICT tools Adopted At KKU For E-Learning is given in Table II.

\section{STATISTICS OF E-LEARNING AT KKU}

Presented by the e-test management department, the Elearning deanship is proud of the leap of success taken by the e-testing process which is considered a first time ever 
accomplishment in the history of e-learning in King Khalid university, where only in the year 2010/2011 the university has had 288 e-tests including 11170 students. The statistics for the usage of e-learning for the year 20112012 as follows:

When comparing the numbers to previous years the development and success is outstanding, while the statistics are the clear evidence to this success.

\section{CONCLUSION}

This case study addressed the need to bring together principles of quality management, at KKU.

To ensure quality in E-learning in KKU, it is recommended that

- Teachers in e-learning programmes should given mandatory training and retraining of ICT programmes to provide them with practical and functional knowledge of the computer, internet and associated areas of ICT.

- Internet Connectivity: Connectivity refers to the quality and extent of the internet infrastructure. KKU needs to lead in broadband connectivity, as effective online learning cannot take place if the internet disconnection exists.

- Providers of e-learning should strive to use quality and reliable ICT hardware and software supported by highly skilled personnel armed with knowledge and skills needed to ensure that the system runs smoothly.

- If Face book or Twitter for example tools are to be used in e-learning, so each student is better to have a separate page to discuss his/her own ideas and problems generally .

- The quality circle approach should be adopted in the designing of course contents and learning materials to ensure quality in course content delivery.

- On-line assessment of students work and end of course examination should be encouraged in elearning programmes. This will check examination malpractices and hence, enhance quality of assessment of student's performance.

This study also provides evidence that these domains can be successfully integrated in near future to support an e-learning unit at KKU for great success.

\section{REFERENCES}

[1] Akpan. C. P. \& Esirah, E., Strategies for Realistic Quality Assurance in Knowledge Generation in Tertiary Institutions in Nigeria.In N. Ezeh \& N. Onyegegbu (eds), 2005.

[2] Asim, A. E \& Okon, J. E., Strategizing For Realistic Quality Assurance in the Nigerian University System. In D.N. Ezeh \& N. Onyegegbu (eds). Knowledge Generation and Dissemination: Issues and Challenges in Nigerian Universities. Enugu: Pearls \& Gold, 2005.

[3] Bhattacharya, I. \& Sharma, K., 'India in the knowledge economy an electronic paradigm', International Journal of Educational Management Vol. 21 No. 6, 2007. http://dx.doi.org/10.1108/ $\underline{09513540710780055}$

[4] Bottino, R. M., 'ICT, national policies, and impact on schools and teachers' development' 'CRPIT '03: Proceedings of the 3.1 and 3.3 working groups conference on International federation for information processing', Australian Computer Society, Inc., Darlinghurst, Australia, Australia, 3-6, 2003.

[5] Cavanaugh C., Distance Education Quality; University of North Florida, USA,2010.
TABLE I.

USAGE OF E-LEARNING

\begin{tabular}{|l|l|}
\hline Active students & $35426 / 49658 \quad(71.3 \%)$ \\
\hline Active instructor & $1531 / 2011 \quad(76.5 \%)$ \\
\hline Active courses & $3139 / 7152 \quad(43.8 \%)$ \\
\hline Full online courses & 48 courses \\
\hline Blended courses & 341 courses \\
\hline Video conference sessions & 1835 \\
\hline iPad & 200 \\
\hline e-test & 491 \\
\hline Average number of students & 8898 students \\
\hline Average page views per day & 254035 \\
\hline
\end{tabular}

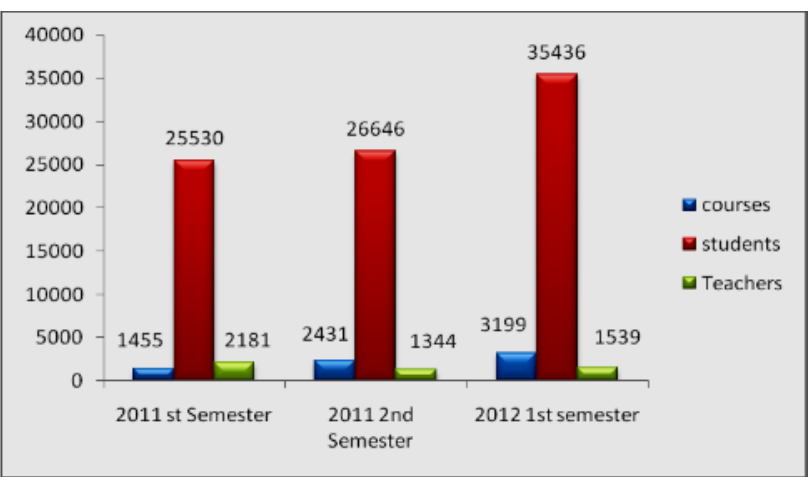

Figure 2. Online activity statistics of e-Learning

[6] Chandra, S. \& Patkar, V., 'ICTS: A catalyst for enriching the learning process and library services in India', The International Information \& Library Review 39(1), 1-11,2007. http://dx.doi.org/10.1016/j.iilr.2006.11.001

[7] Cholin, V. S., 'Study of the application of information technology for effective access to resources in Indian university libraries', The International Information \& Library Revie, 2005.

[8] Cross, M. \& Adam, F., 'ICT Policies and Strategies in Higher Education in South Africa: National and Institutional Pathways', Higher Education Policy 20(1), 73-95, 2007. http://dx.doi.org/10.1057/palgrave.hep.8300144

[9] Cysewski Stephen., E Learning Ideas; Retrieved on 21 March 2010 http://www.cysewski.com/sabbatical/elearningexamples.

[10] Fadipe, J. O., Efficiency Indicators for Quality Control in Nigerian School System. In J.O Fadipe \& D.K. Ojedele (eds) Management of Nigerian Education: Personnel Administration and Quality in Education. NIEPA, Nigeria, 2000.

[11] Lim, C. P. \& Chai, C., 'An activity-theoretical approach to research of ICT integration in Singapore schools: Orienting activities and learner autonomy', Computers \& Education,2004. http://dx.doi.org/10.1016/j.compedu.2003.10.005

[12] Lim, C. P. \& Hang, D., 'An activity theory approach to research of ICT integration in Singapore schools', Computers \& Education 41(1), 49-63, 2004. http://dx.doi.org/10.1016/S0360-1315(03)00 $\underline{015-0}$

[13] Lindsay, A., Concepts of Quality in Higher Education, Journal of Tertiary Education Administration 14(2): 153-163, 1992. http://dx.doi.org/10.1080/1036970920140203

[14] Lucey, T.,Management Information System (9th Edition). Book Power,2005.

[15] Maduewesi, E. J.,Benchmarks and Global Trends in Education. Benin City, Nigeria. Dasylva, 2005.

[16] Mason, R., 'From distance education to online education', The Internet and Higher Education 3(1-2), 63-74, 2000. http://dx.doi.org/10.1016/S1096-7516(00)00033-6

[17] Mooij, T., 'Design of educational and ICT conditions to integrate differences in learning: Contextual learning theory and a first transformation step in early education', Computers in Human Behavior 23(3), 1499-1530, 2007. http://dx.doi.org/10.1016/j.chb. 2005.07 .004 
[18] Okebukola, P.,Quality Assurance in the Nigerian University System. Keynote address Presented at the 2005 Fellowship Seminar /Award of the Curriculum Organization of Nigeria held at the University of Jos, Nigeria on 6th April, 2005.

[19] Plomp, T.; Pelgrum, W. J. \& Law, N., 'SITES2006-International comparative survey of pedagogical practices and ICT in education', Education and Information Technologies, 2007. http://dx.doi.org/10.1007/s10639-007-9029-5

[20] Sanyal, B. C., New functions of higher education and ICT to achieve education for all, Paper prepared for the Expert Roundtable on University and Technology-for- Literacy and Education Partnership in Developing Countries, International Institute for Educational Planning, UNESCO, September 10 to 12, Paris, 2001.
[21] UNESCO, Open and Distance Learning: Trends, Policy and Strategy Consideration, 2002.

\section{AUTHORS}

Dr.Anandhavalli is with Department of CS \& IS, Women Campus, KKU, Abha, Saudhi Arabia (e-mail: anandhavalli@kku,edu.sa).

Ms.Fatimah Alsaif is with Department of CS \& IS, Women Campus, KKU, Abha, SaudhiArabia, (email:Fatimah-Saif@ hotmail.com).

Received 29 October 2012. Published as resubmitted by the authors 27 February 2013. 